\title{
A new ladybird spider from Hungary (Araneae, Eresidae)
}

\author{
Gábor Kovács', István Prazsák², János Eichardt³ , Gábor Vári, Henrik Gyurkovics ${ }^{5}$ \\ I Dózsa tér 4., Bordány, H-6795 Hungary 2 Department of Medical Biology, Faculty of Medicine, University \\ of Szeged, Dugonics tér 13., Szeged H-6720 Hungary 3 Arachnological Laboratory, University of West \\ Hungary, Károlyi Gáspár tér 4., Szombathely H-9700 Hungary 4 Information Technology Department, Albert \\ Szent-Györgyi Health Center, University of Szeged, Tisza L. krt. 107., Szeged H-6720 Hungary 5 Biological \\ Research Centre, Hungarian Academy of Sciences, Temesvári krt. 62., Szeged H-6726 Hungary
}

Corresponding author: Gábor Kovács (gabor.kovacs.arachnida@gmail.com)

Academic editor: Jeremy Miller | Received 1 October 2014 | Accepted 13 March 2015 | Published 6 April 2015

http://zoobank.org/E303FC86-F654-416C-A5D8-59C34044C60C

Citation: Kovács G, Prazsák I, Eichardt J, Vári G, Gyurkovics H (2015) A new ladybird spider from Hungary (Araneae, Eresidae). ZooKeys 494: 13-30. doi: 10.3897/zookeys.494.8676

\begin{abstract}
According to the most recent taxonomic literature, three species of the genus Eresus are known in Central Europe, E. kollari, E. sandaliatus and E. moravicus. We recognized a fourth distinctive species from Hungary, which is described as Eresus hermani sp. n. Eresus hermani has an early spring copulation period, females have a light grey (grizzled) cephalothorax due to a heavy cover of lightly colored setae, and an epigyne with large flat areas posterior to the epigynal pit, while males are distinguished by a broad and blunt terminal tooth of the conductor. An updated and modified comparative table of Řezáč et al. (2008) to include all four Central European Eresus species, and a simple key to the species group's species are given. Habitus, epigyne, vulva and conductor of E. kollari, E. moravicus and E. sandaliatus are also illustrated. An annotated list of papers illustrating $E$. hermani due to misidentifications is presented.
\end{abstract}

\section{Keywords}

Ladybird spiders, Eresus

\section{Introduction}

The velvet spiders (family Eresidae) are among the most attractive spiders in Europe. The family contains nine genera and 96 described species worldwide. The genus Eresus

Copyright Gábor Kovács et al. This is an open access article distributed under the terms of the Creative Commons Attribution License (CC BY 4.0), which permits unrestricted use, distribution, and reproduction in any medium, provided the original author and source are credited. 
Walckenaer, 1805 contains 15 valid species from Europe, Africa and Asia, of which nine occur in Europe (World Spider Catalog 2015).

According to the latest studies (Řezač et al. 2008, Miller et al. 2012) three species of the Eresus sandaliatus group, Eresus kollari Rossi, 1846, E. sandaliatus Martini \& Goeze, 1778 and E. moravicus Řezáč, 2008, occur in Central Europe.

The long and complicated scientific history of the Eresus sandaliatus group sensu Miller et al. (2012) is discussed in detail in Řezač et al. (2008), so only the Hungarian perspective is described here. The nomenclatural chaos is well illustrated by the fact that E. cinnaberinus might become valid, possibly as a senior synonym of E. kollari (Azarkina and Trilikauskas 2012).

The Hungarian spider fauna was first studied in detail by Ottó Herman, who also gave a detailed description of the Eresus genus (Herman 1879). Herman indicated the presence of two species, E. ruficapillus C. L. Koch, 1846 (regarded as misidentification of E. moravicus by Rezač et al. 2008 due the "reddish-yellowish hairs on the female") and E. kollari (as E. cinabarinus Olivier), distinguishing $a, \beta$, and $\gamma$ color variants, the latter corresponding to $E$. moravicus.

However, subsequent authors (e. g. Chyzer and Kulczynski 1918, Samu and Szinetár 1999) recognized only one species, E. cinnaberinus, with adults during the autumn.

Loksa (1969) mentioned a color form of female Eresus (E. niger var. ruficapillatus C.L. Koch) from the Mecsek hills and from the vicinity of lake Balaton, which has yellowish hairs on the carapace front, later identified as E. moravicus by Řezač et al. (2008).

Recently, Řezáč et al. (2008) considered E. cinnaberinus as nomen dubium [but see personal communication of Rezáč referred to in Azarkina and Trilikauskas (2012) as it might not] and proposed the name E. kollari Rossi, 1846 as valid. In this revision a

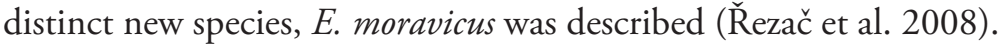

Eresus cinabarinus $\gamma$-color variant of Herman (1879), E. ruficapillus C.L. Koch and E. niger var. ruficapillatus (in Loksa 1969) were all identified as E. moravicus by Řezač et al. (2008). This means two Hungarian Eresus species, E. moravicus with a late spring-early summer copulation period, and E. kollari with populations mating in autumn (Kovács et al. 2010).

During an ongoing project aimed at mapping the distribution of Eresidae in Hungary, the presence of an Eresus species was observed with an early spring copulation period, which has unique morphological characters, and is described here as new to science.

\section{Materials and methods}

Specimens were either collected individually or by using pitfall traps, and stored in $70 \%$ ethyl-alcohol.

We studied 31 males, 15 females and 6 juveniles of E. kollari; 20 males, 25 females and 4 juveniles of $E$. hermani sp. n., and 19 males, 11 females and 3 juveniles of $E$. moravicus, and 2 males, 3 females and 2 juveniles of $E$. sandaliatus. All the measurements are given in millimeters $(\mathrm{mm})$. 
All specimens of the new species examined, including holotype and four paratypes, have been deposited in the Soil Zoological Collection (former Arachnoidea Collection) of the Department of Zoology, Hungarian Natural History Museum (HNHM) Budapest (curator Dr. László Dányi).

Specimens and copulatory organs were studied using a Leica MZ FL III stereomicroscope and photographed by Canon Q Imaging Micro 5.0 RTV at the Institute of Genetics, BRC. Scanning electron micrographs were taken with a Hitachi S- 4700 microscope at the Department of Applied and Environmental Chemistry, University of Szeged, Hungary.

\section{Abbreviations}

Standard abbreviations of morphological terms follow Miller et al. (2012). Further abbreviations: $\mathbf{P M E}=$ posterior median eyes, $\mathbf{P L E}=$ posterior lateral eyes, $\mathbf{F e}=$ femur, $\mathbf{P t}=$ patella, $\mathbf{T i}=$ tibia, $\mathbf{T a}=$ tarsus, $\mathbf{M t}=$ metatarsus, $\mathbf{M L}=$ median lobe of epigyne, $\mathbf{L}=$ leg, juv. = juvenile.

HNHM Hungarian Natural History Museum, Budapest;

NHMW Naturhistorisches Museum, Wien;

PPI Plant Protection Institute of the Hungarian Academy of Sciences, Budapest; JLPC private collection of Jørgen Lissner;

WPPC private collection of Walter Pfliegler.

Translation of Hungarian geographical names in the description of collection material is -hegy: hill; -völgy: valley.

\section{Results}

\section{Taxonomy}

\section{Eresus hermani sp. $\mathbf{n}$.}

http://zoobank.org/CE9C2B06-FBAC-4246-BD75-EC716F94C34F

Figs 1A-B, 3A-C, 4A-B, 5A-B, 6A-B, 7A

Eresus cinnaberinus Szinetár 2006 p 22 fig. 3 (misidentified)

Eresus kollari Kovács et al. 2010 fig. 1C-F, 2D (misidentified)

Eresus kollari Miller et al. 2012 fig. 2A (misidentified)

Eresus kollari Szinetár et al. (2012): table 2, figure 6 (misidentified)

Material examined. Holotype: Female - HUNGARY, Budapest, Remete-hegy, N 47³2'26.3", E 1900'24.1", singled, 23.04.2011., G. Kovács (HNHM, collection number: HNHM Araneae 7612). 

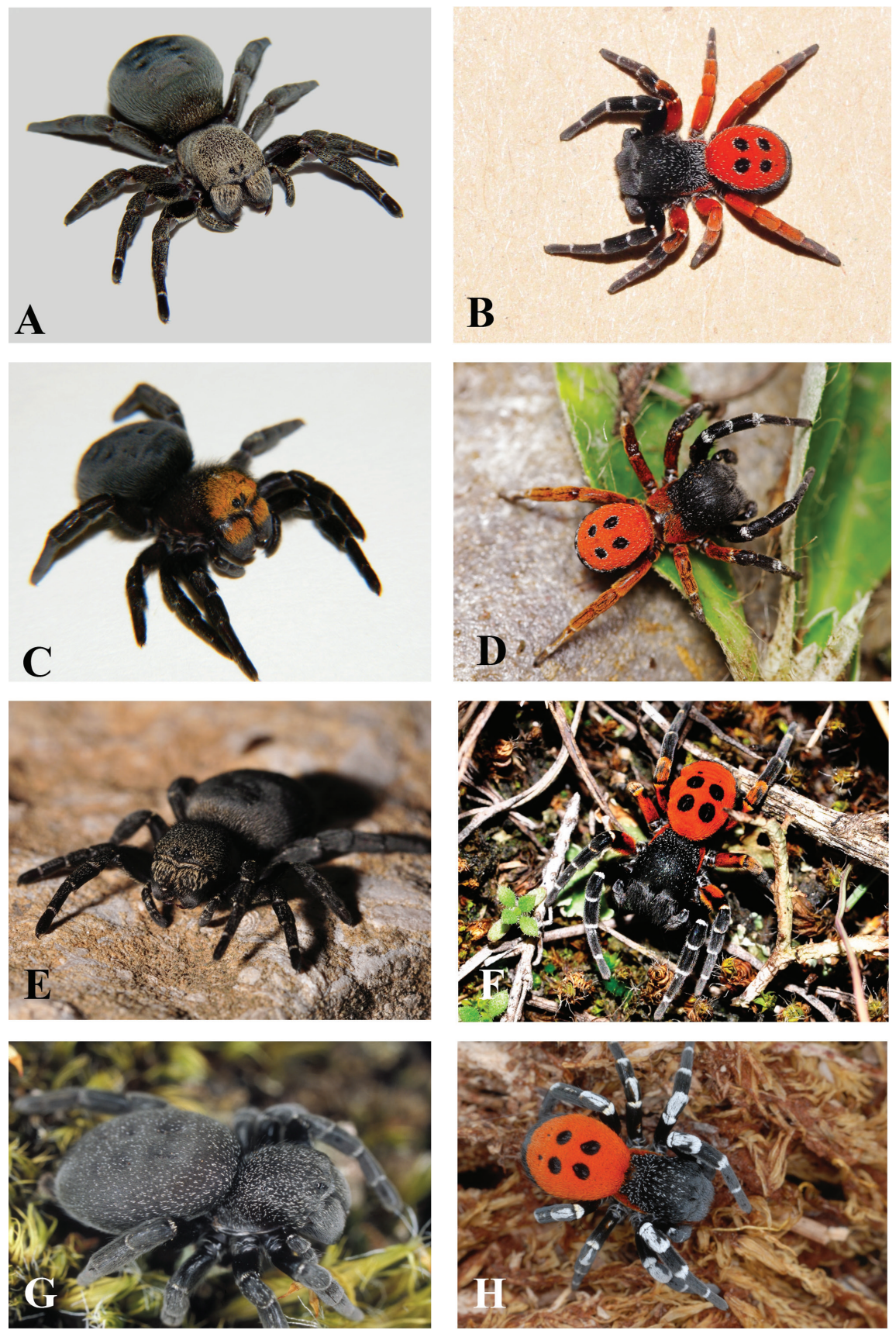

Figure I. A-H Habitus of living Eresus species, photographs: A-B Eresus hermani $\mathbf{A}$ female (Remetehegy, Budapest, Hungary) B male (Farkas-hegy, Budaörs, Hungary) C-D Eresus moravicus C female (Misina-hegy, Pécs, Hungary) D male (Dürnstein, Austria) E-F Eresus kollari E female (Paloznak, Hungary) F male (Kéleshalom, Hungary) G-H Eresus sandaliatus $\mathbf{G}$ subadult female (near to Silkeborg Langsø, Enebærbakken, Denmark) $\mathbf{H}$ male (Nørlund, Hallundbæk Stream, Denmark) (D courtesy of Walter Pfliegler G-H courtesy of Jørgen Lissner). 
Paratypes: 2 females - HUNGARY, Budapest, Sas-hegy, N 47²8'47.2", E $19^{\circ} 01$ '04.4", singled, 02.10.2013., G. Kovács, H. Gyurkovics, G., Vári, A. Rákóczi (HNHM, collection number: HNHM Araneae-7630-31). - 2 males HUNGARY, Budapest, Remete-hegy, N 47³2'26.3", E 1900'24.1", singled, 23.04.2011., G. Kovács, (HNHM, collection number: HNHM Araneae: 7632-33).

Remark. The genus Eresus in Central Europe has a long and difficult nomenclatural history. Some available "old names" were examined, such as Eresus illustris (presently considered nomen dubium, specimens are irretraceable), which is marked as possibly Hungarian (despite the fact Koch himself wrote "Vaterland: Unbekannt" [trans. Locality: Unknown]), but discarded it on the basis of the description and color image (Koch 1838, fig. 317), where the male has six black dots on the opisthosoma and only the dorsal side of hind femora as red, whereas $E$. hermani males have only four dots and clearly red hind legs patellae and tibiae, without any black, and tarsi and metatarsi are brownish grey (Fig. 1B). The female of E. illustris is unknown. The other possible candidate, E. fulvus Rossi 1846 (type specimens can no longer be found in NHMW), described by female specimens only, can also be excluded as a potential synonym, since they all have a large area covered by yellow/orange setae on the cephalothorax ["nitide fulvus" in the description of Rossi (1846)], whereas E. hermani females have no truly yellow setae on the prosoma at all; instead, its dorsal cephalothorax is light brownishgrey overall. According to Rezáč et al. 2008 (page 275.) E. fulvus Rossi differs from E. moravicus by "having spermatheca that are less lobed, and having copulatory ducts that are almost horizontal in the centre of the vulva." By contrast, spermathecae of $E$. hermani are rather conspicuously lobed, at least as much as in Eresus moravicus (Figs 4C, F and 5B, D).

Etymology. Dedicated to Ottó Herman (1835-1914), the Hungarian arachnologist and polymath, who first recognized color variants within Hungarian Eresus forms, to commemorate the $100^{\text {th }}$ anniversary of his passing.

Diagnosis. Females of this species differ from all other Eresus females by the carapace's short, off-white to light brown hairs, intermingled with small clumps of long, black hairs, giving a light, grizzled appearance to the prosoma, and by an epigyne with a pair of flat plateaus adjoining the sides of the broad median lobe laterally. Males are characterized by the narrow groove and blunt, broad terminal tooth of the conductor, and distinguished from other Eresus species, except E. moravicus, by having almost entirely red hind legs. They differ from E. moravicus males by having red color on the thoracic dorsum only laterally, having a less prominent cephalic region with an almost flat area between PLE and PME, and by narrower strips of white setae on L I. This species has an early spring copulation period, and exhibits a marked difference in the sizes of the sexes: males are relatively small, while females are comparatively large among Central European Eresus spp. (Table 1).

Description. Male. Prosoma (Fig. 1B): Length 2.9-4.1 (mean 3.4, $\mathrm{N}=15)$ Prominent, color dark ferruginous brown, covered by long, black hairs intermingled with scattered, short, white ones. Cephalic region barely broader than thoracic part, weakly broadening towards the front, steeply raised posteriorly, but area between PME 


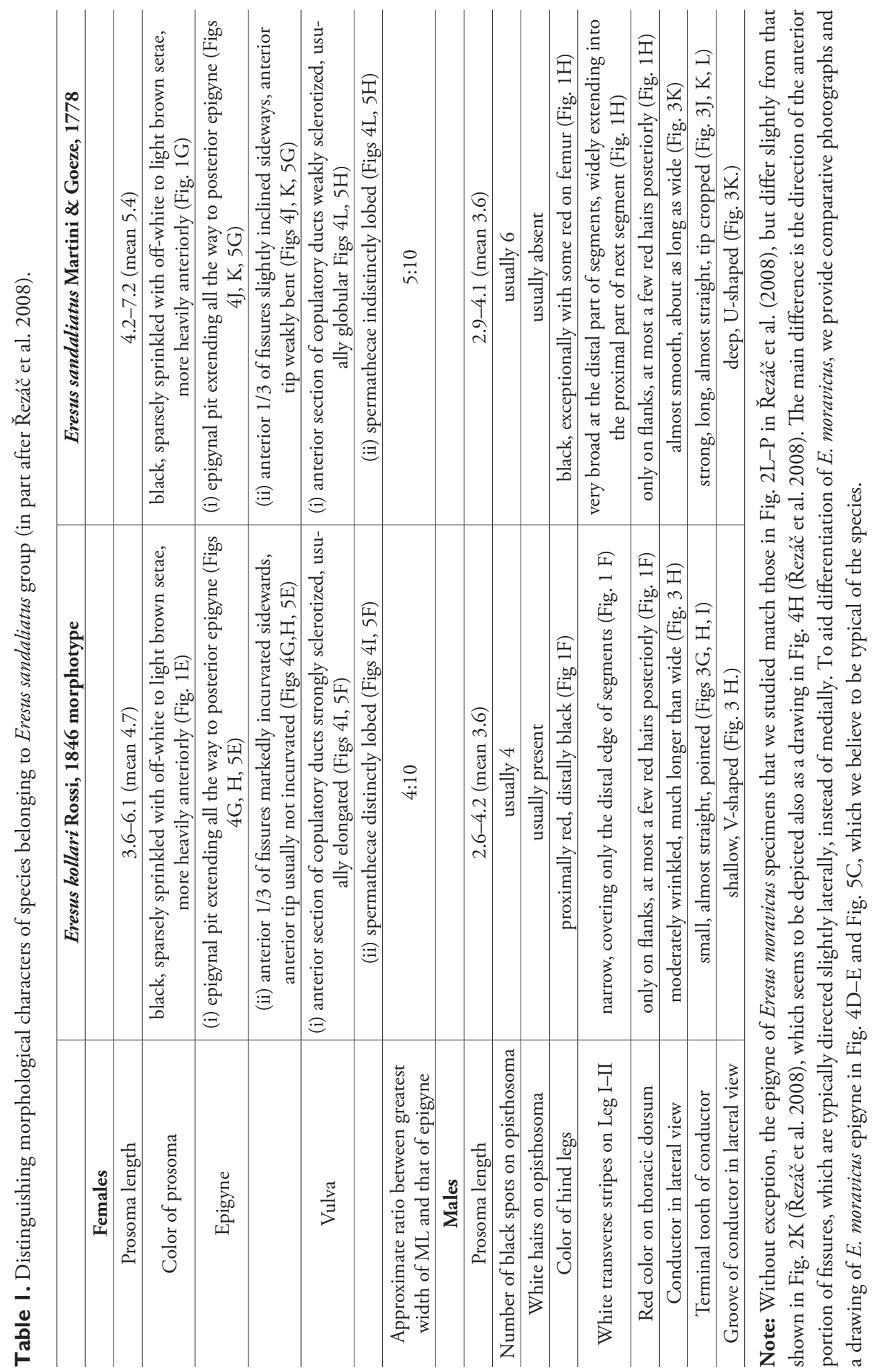




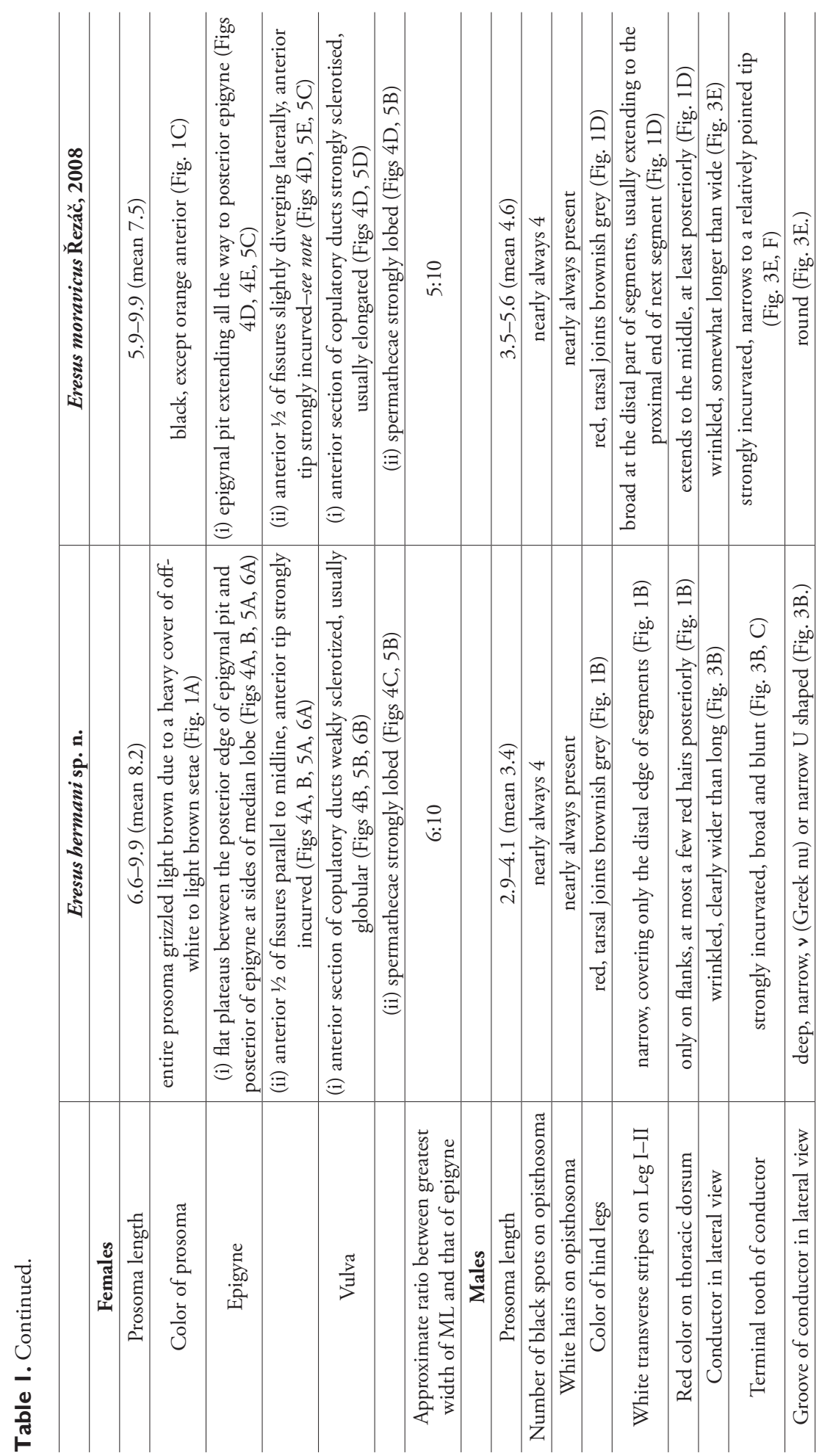


and PLE nearly flat. Thoracic part bordered laterally by narrow red stripes, never extending to posterior dorsum.

Chelicerae: Blackish-brown, covered by long, nearly adpressed black hairs; basal half with scattered white hairs on the front.

Legs: Legs I-II dark orange-brown with black hairs; Fe II and Pt II orange with red hairs, Ti II often with a dorsal patch of red hairs. Distal edges of Fe, Pt, Ti and Ta with narrow, white stripe dorsally, usually not extending to the proximal part of the next distal segment. Legs III and IV largely orange, covered with red hairs, Ta and Mt dull grayish-brown due to a mixture of reddish and black hairs, except for a proximodorsal patch of red on Mt.

Opisthosoma (Fig. 1B): Dorsally red with scattered white hairs except for two pairs of black spots. Red area and black spots seamed by a more-or less continuous line of white hairs. Ventral side of opisthosoma black with the exception of some red hairs on the branchial opercula.

Palps (Fig. 3A-C): Conductor broad, strongly wrinkled. Terminal tooth broad and blunt, somewhat longer than the lamella, with a strong, sudden bend at the base or somewhat more distally. Groove deep, narrow, $\nu$ (Greek nu) or narrow U shaped at the base in lateral view. Inner, spiny lamella high, about as high as terminal tooth.

Female. Prosoma (Fig. 1A): Length 6.6-9.9 (mean 8.2, n = 21), prominent, especially the cephalic region, dark orange-brown with a heavy cover of short, off-white to light brown hairs and with scattered, small clumps of long, black hairs giving a grizzled appearance.

Chelicerae: Dark orange brown, front of basal 1/3-3/4 same color as prosoma.

Legs: Rusty red, Fe, Pt, Ti and Mt of all legs covered by black hairs with pale brown hairs scattered among them, the latter gradually decreasing in number from L I to L IV, usually clustering to form indistinct cross bands dorsally at the distal edge of each segments. Ta usually black, except for a small cluster of pale hairs basally.

Palps: Similar in color to L I.

Opisthosoma (Fig. 1A): Brownish-black, covered by long black hairs with a scattering of short pale hairs at its anterior.

Epigyne (Figs 4A, 5A, 6A): Moderately deep, median lobe broad (ratio between the greatest width of ML to the greatest width of epigyne: 6:10), considerably flared posteriorly, reaching well over the posterior margin of the epigynal pit. Posterior edge of the epigynal depression not reaching posterior epigyne, but followed by a pair of flat, somewhat wrinkled plateaus adjoining the fissures laterally. Posterior part of fissures inclined towards the midline, turning parallel to the longitudinal axis before the short, incurved anterior tips.

Vulva (Figs 4B, 5B, 6B): Spermathecae distinctly lobed, reaching further laterally than copulatory ducts. Anterior part of copulatory ducts weakly sclerotized, usually circular, exceptionally elongated in outline. 


\section{Simplified key to the species of the Eresus sandaliatus group}

\section{Females}

1 Anterior of cephalic region covered by bright yellow/orange setae

- $\quad$ No bright yellow/orange setae on prosoma

Eresus moravicus

2 Entire prosoma covered heavily by off-white to light brown setae; large....

Eresus hermani sp. n.

- $\quad$ Prosoma sparsely sprinkled with lightly colored setae, somewhat more heavily on the front; smaller

3 Anterior of fissures only slightly inclined sideways, as in Fig. 5G, spermathecae indistinctly lobed, anterior of copulatory ducts nearly round in outline, weakly sclerotized

Eresus sandaliatus Anterior of fissures markedly incurvated sideways, as in Fig. 5F, spermathecae distinctly lobed, anterior of copulatory ducts elliptical, strongly sclerotized...

Eresus kollari

\section{Males}

1 Terminal tooth of conductor strongly incurvated, hind legs almost entirely

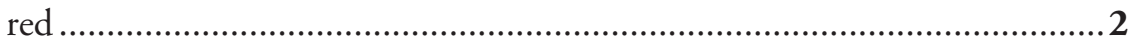

- $\quad$ Terminal tooth of conductor nearly straight, at most weakly bent, red areas on hind legs not so extensive or entirely absent ........................................... 3

2 Conductor with a blunt terminal tooth and a narrow groove, prosoma barely broadens towards front ............................................ Eresus hermani sp. n.

- Conductor with a pointed terminal tooth and a round groove, prosoma strongly broadens towards front. .....

Eresus moravicus

3 Conductor with a strong, long and slightly bent terminal tooth and a Ushaped (in lateral view) groove, hind legs nearly devoid of red setae.

Eresus sandaliatus

- Conductor with a short, straight terminal tooth and a V-shaped (in lateral view) groove, hind legs with extensive areas of red color Eresus kollari

\section{Distribution.}

Known from seven localities (Fig. 2): Budapest: Remete-hegy (locus typicus), Mátyás-hegy, Sas-hegy, Budaörs: Farkas-hegy, Érd: Fundoklia-völgy and Várpalota-Inota: Víztározó, Baglyas-hegy. With the exception of Érd: Fundoklia-völgy, E. hermani proved to be syntopic with E. kollari, whereas all three Eresus sp. occurring in Hungary, E. hermani, E. kollari and E. moravicus are syntopic at Várpalota-Inota: Baglyas-hegy.

Habitat. Edges of a local variety of downy oak scrub woodland (Ceraso mahalebQuercetum pubescentis) and the interim zone between calcareous open rocky grasslands (Seselio leucospermi-Festucetum pallentis) and degraded scrubland. 


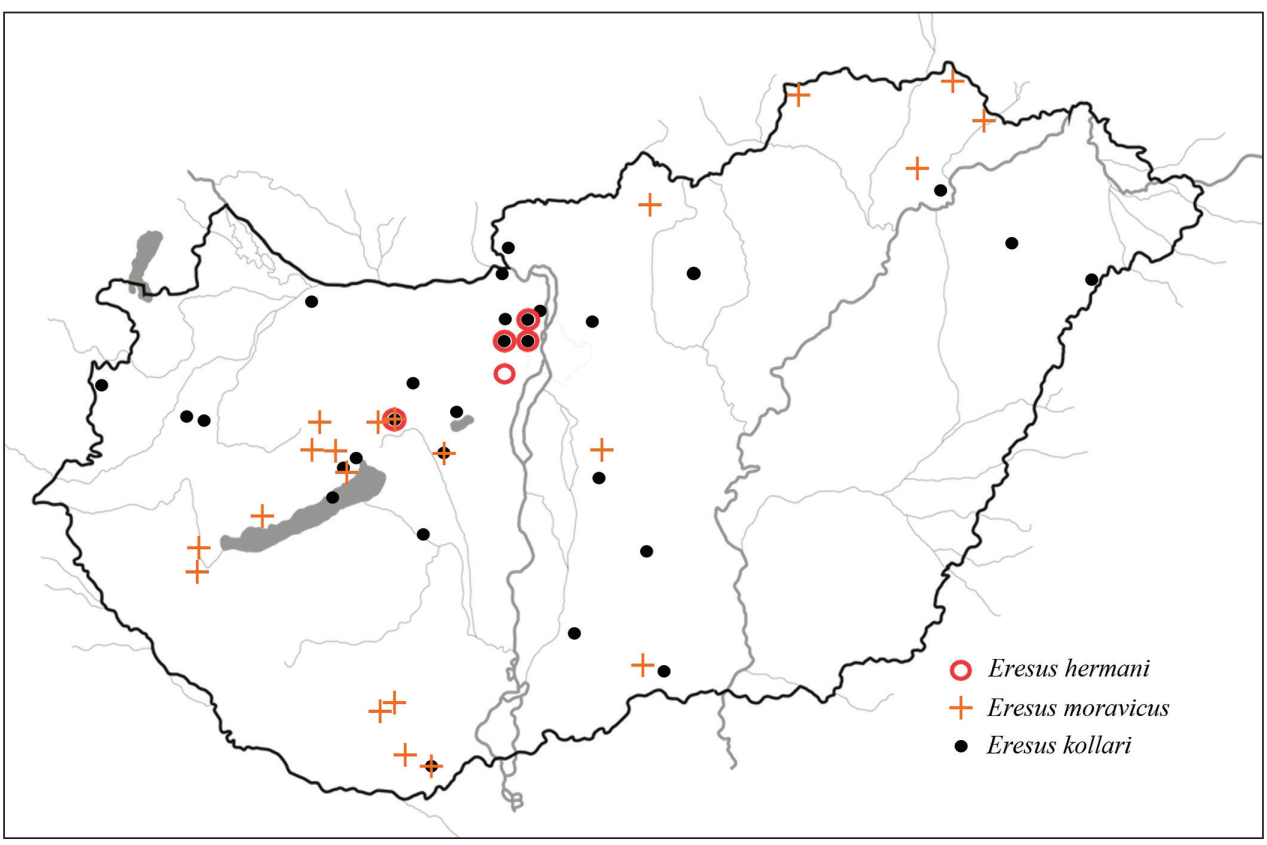

Figure 2. Known localities of all three Eresus species occurring in Hungary.

Phenology. Eresus hermani matures in August-September, wandering males can be found from the end of March to the end of April (inferred copulation period) and females lay eggs in June. This phenology clearly sets Eresus hermani apart from the other Hungarian Eresus species: E. moravicus matures in late spring and mates in early summer, while $E$. kollari matures in late summer - early autumn, immediately followed by a copulation period in autumn. The phenology of Eresus hermani is essentially the same as that of $E$. sandaliatus (Řezač et al. 2008), which, however, does not occur in Hungary or within the Carpathian Basin.

Additional material examined. Hungary: Remete-hegy, Budapest (1 $q$, 01.11.2008., G. Kovács, HNHM Araneae-7669); Remete-hegy, Budapest (1 q, 02.09.2008., G. Kovács, HNHM Araneae-7670); Remete-hegy, Budapest (3 \&, 2 ô, 05.04.2008., G. Kovács, HNHM Araneae-7671); Remete-hegy, Budapest (1 ㅇ, 1 juv., 18.04.2008., G. Kovács, HNHM Araneae-7672); Farkas-hegy, Budaörs (1 +, 22.09.2013., G. Kovács, H. Gyurkovics, G. Vári, D. V. Nagy, HNHM Araneae-7673); Farkas-hegy, Budaörs (2 ð̊, 14.04.2013., H. Gyurkovics, G. Vári, HNHM Araneae-7674; Sas-hegy, Budapest (4 Ō, 07.04.2012., A. Rákóczi, HNHM Araneae-7675); Sas-hegy, Budapest (4 đ̃, 25.03.2012., A. Rákóczi, HNHM Araneae-7676); Remete-hegy, Budapest (1 $\delta$, 16.04.2005., G. Kovács, HNHM Araneae-7677; Farkas-hegy, Budaörs (1 Õ, 13.04.2012., G. Kovács, HNHM Araneae-7678); Farkashegy, Budaörs (1 $\widehat{~}$, 21.04.2010., J. Bodor, HNHM Araneae-7679); Remete-hegy, Budapest (5 q, 16.09.2012., G. Kovács, HNHM Araneae-7680); Remete-hegy, Bu- 

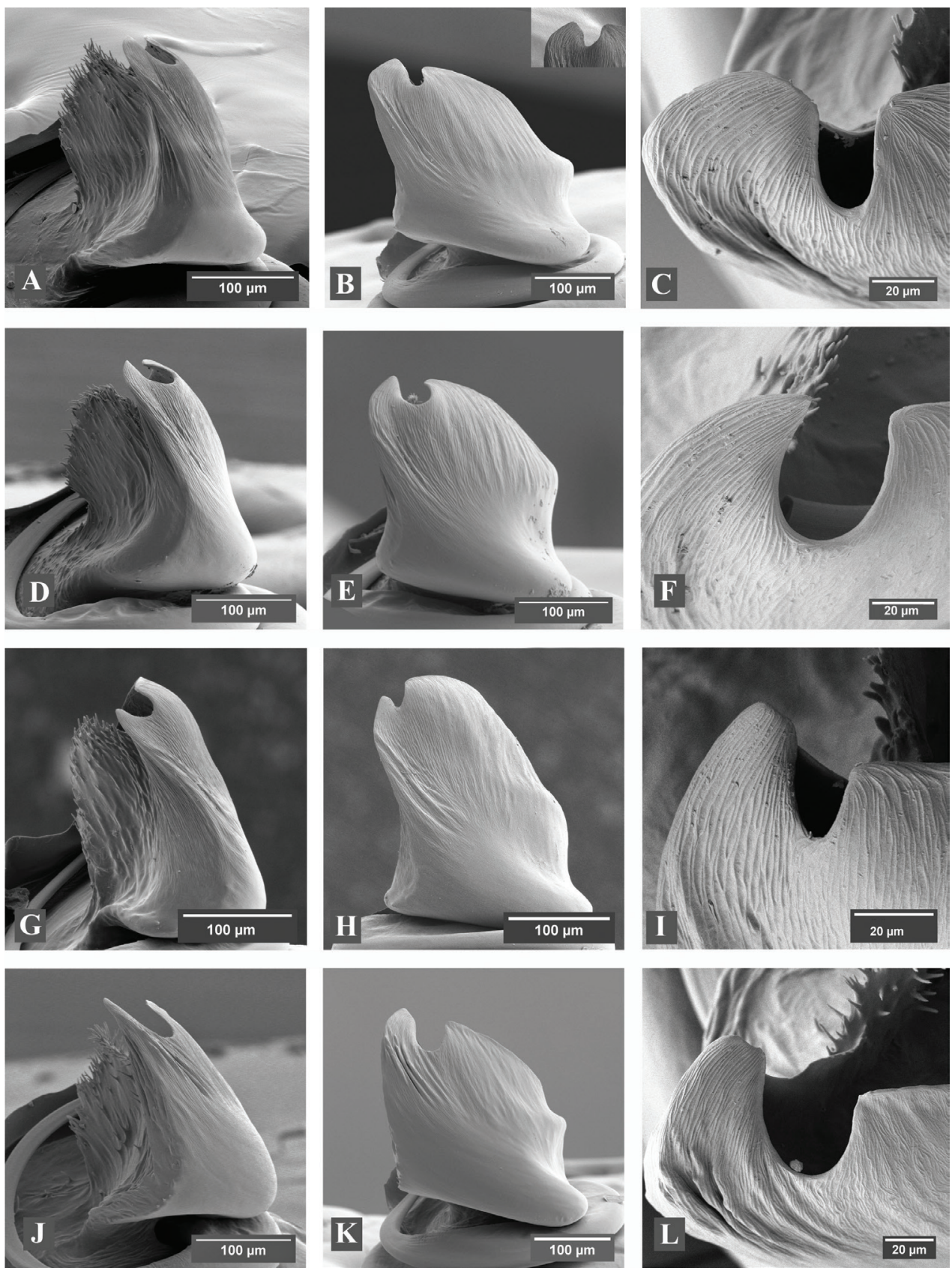

Figure 3. A-L Scanning electron micrographs of Eresus male palps: A-C Eresus hermani (Sas-hegy, Budapest, Hungary) D-F Eresus moravicus (Örkény-Táborfalva-Tatárszentgyörgy, Hungary) G-I Eresus kollari (Farkas-hegy, Budaörs, Hungary) J-L Eresus sandaliatus (Aulum, Denmark) A, D, G, J ventral $\mathbf{B}, \mathbf{E}, \mathbf{H}, \mathbf{K}$ lateral and $\mathbf{C}, \mathbf{F}, \mathbf{I}, \mathbf{L}$ apical view; inset in $\mathbf{B}$ : a variant of conductor tip with unusually wide groove (Sas-hegy, Budapest, Hungary). 


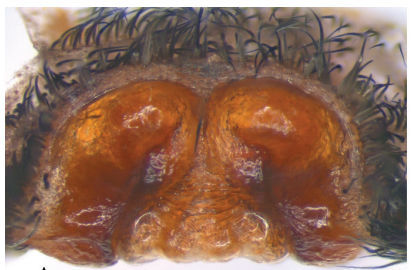

A
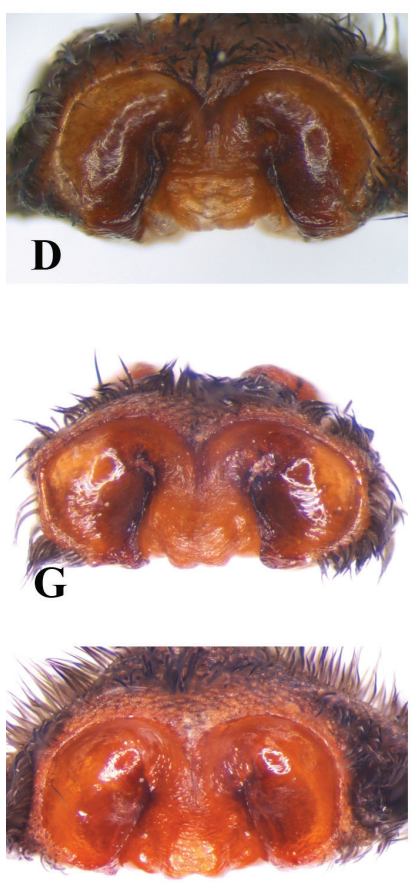

$\mathbf{J}$

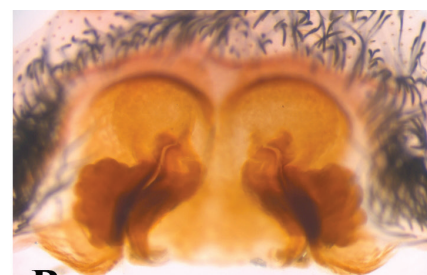

B
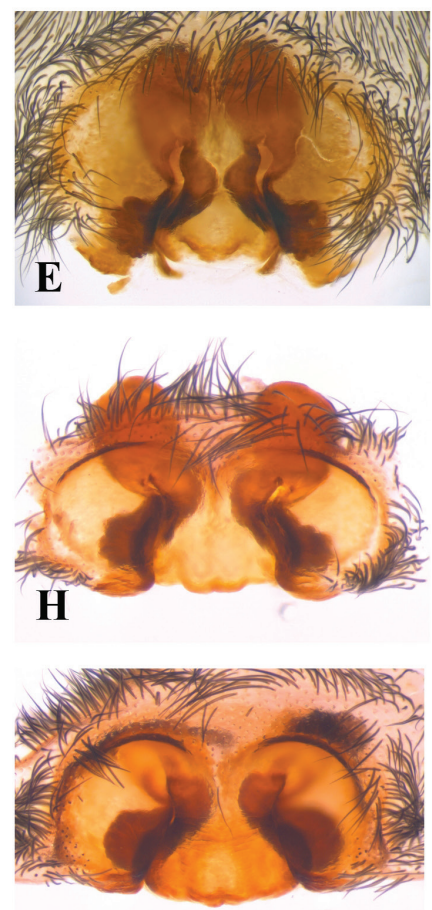

K
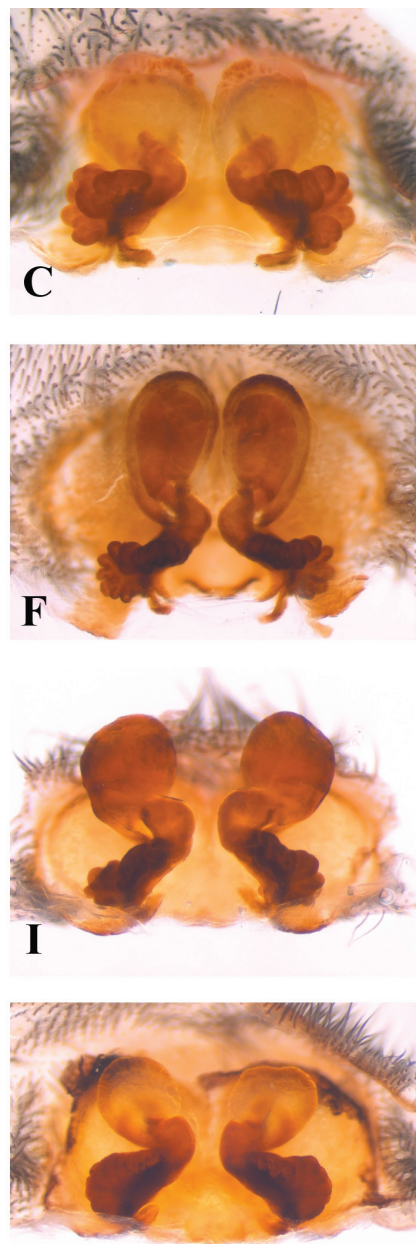

$\mathbf{L}$

Figure 4. A-L Copulatory organs of Eresus adult females: A-C Eresus hermani (Sas-hegy, Budapest, Hungary) D-F Eresus moravicus (D Misina-hegy, Pécs, Hungary E-F Dürnstein, Austria) G-I Eresus kollari (Farkas-hegy, Budaörs, Hungary) J-L Eresus sandaliatus (near to Tranemose moor Northwest Jutland, Denmark) A, D, G, J epigyna B, E, H, K epigyna* C, F, I, L vulvae* (*: macerated).

dapest (1 +, 28.09.2008., G. Kovács, HNHM Araneae-7681); Remete-hegy, Budapest (3 9 , 23.04.2011., G. Kovács, HNHM Araneae-7682); Remete-hegy, Budapest (1 + , 31.03.2011., G. Kovács, HNHM Araneae-7683); Sas-hegy, Budapest (6 q, 02.10.2013. H. Gyurkovics, A. Rákóczi, G. Vári, HNHM Araneae-7684); Érd, Fundoklia-völgy (1 + , 02.10.2013. G. Vári, HNHM Araneae-7685-86); Érd, Fundokliavölgy, (1 +, 02.10.2013., G. Kovács, HNHM Araneae-7687); Várpalota-Inota (2 juv., 06.07.2014., G. Kovács, G. Vári, HNHM Araneae-7688), Mátyás-hegy, Budapest (5 đ, 1933, G. Kolosváry, HNHM Araneae-2943). 
A

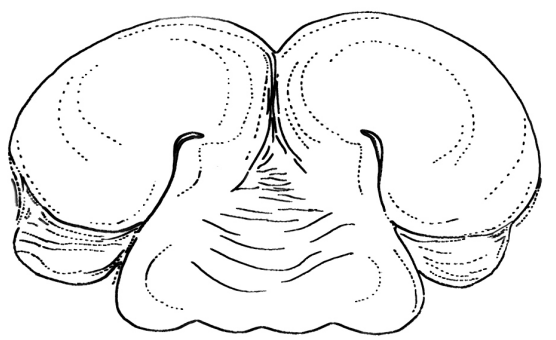

C

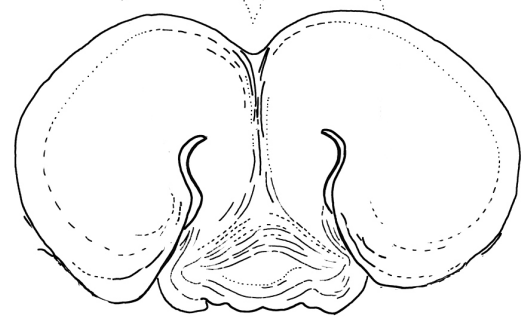

$\mathbf{E}$

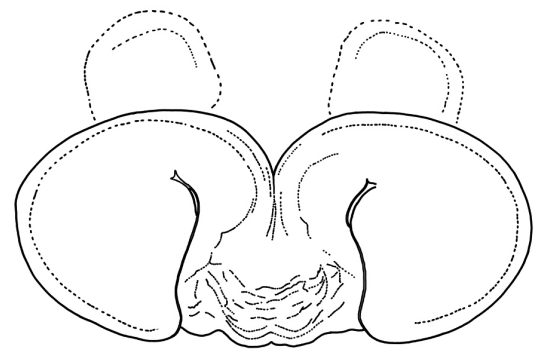

G

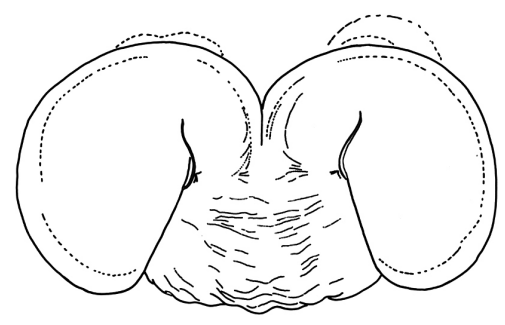

B

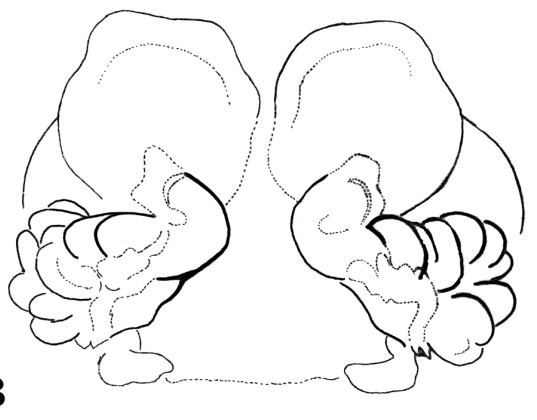

D
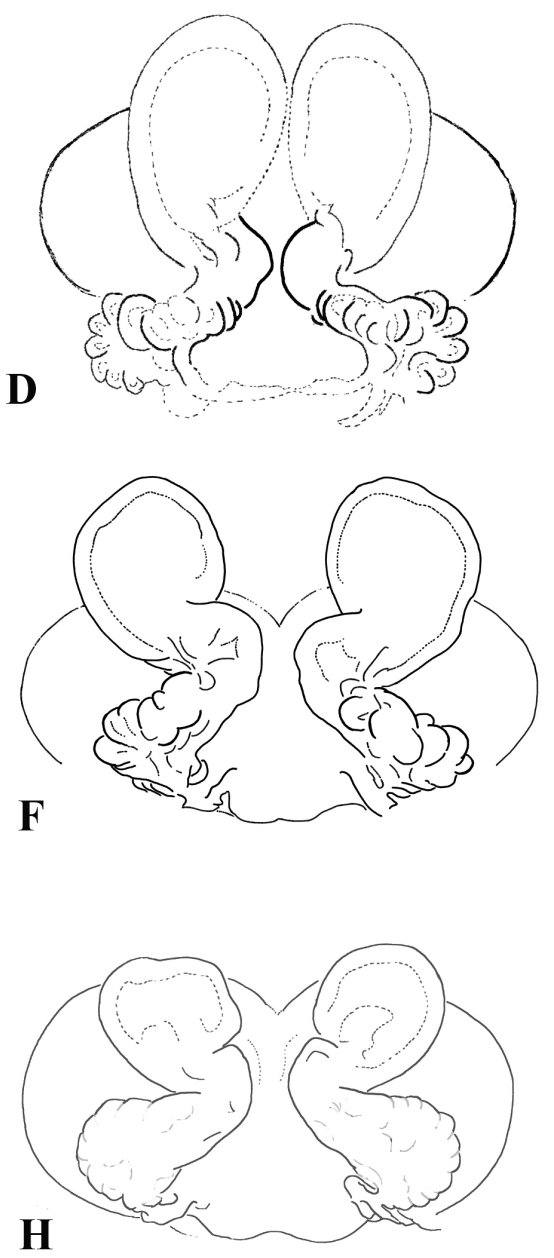

Figure 5. A-H Schematic drawings of Eresus female copulatory organs: A-B Eresus hermani (Sas-hegy, Budapest, Hungary) C-D Eresus moravicus (Dürnstein, Austria) E-F Eresus kollari (Farkas-hegy, Hungary) G-H Eresus sandaliatus (near Tranemose moor, Northwest Jutland, Denmark) A, C, E, G epigyna B, D, F, H vulvae. 

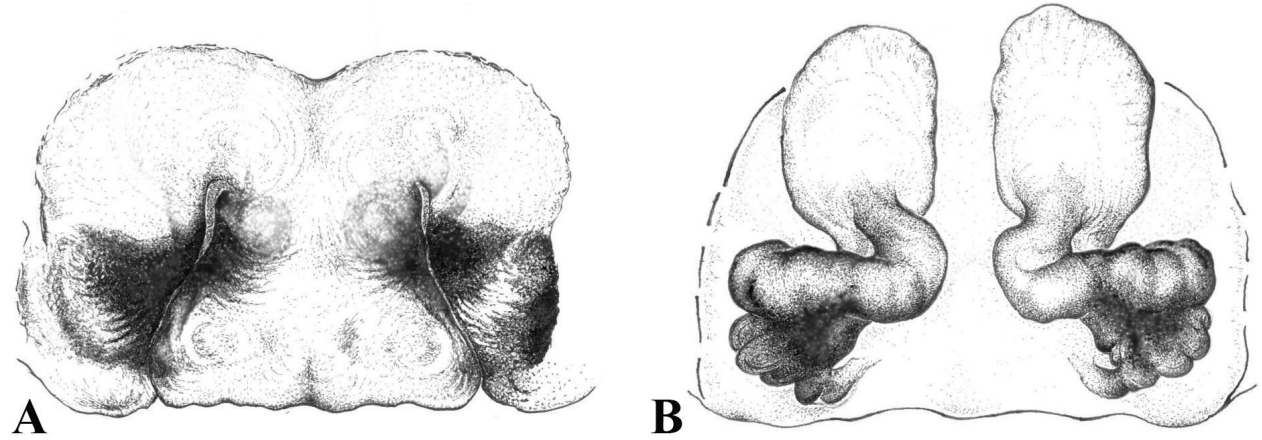

Figure 6. Drawings of Eresus hermani female copulatory organ, rare variant (Fundoklia-völgy, Érd, Hungary): A epigyne B vulva. Note the rounded anterior edge of the plateaus lateral to the median lobe in $\mathbf{A}$ and the elongated copulatory duct in $\mathbf{B}$.
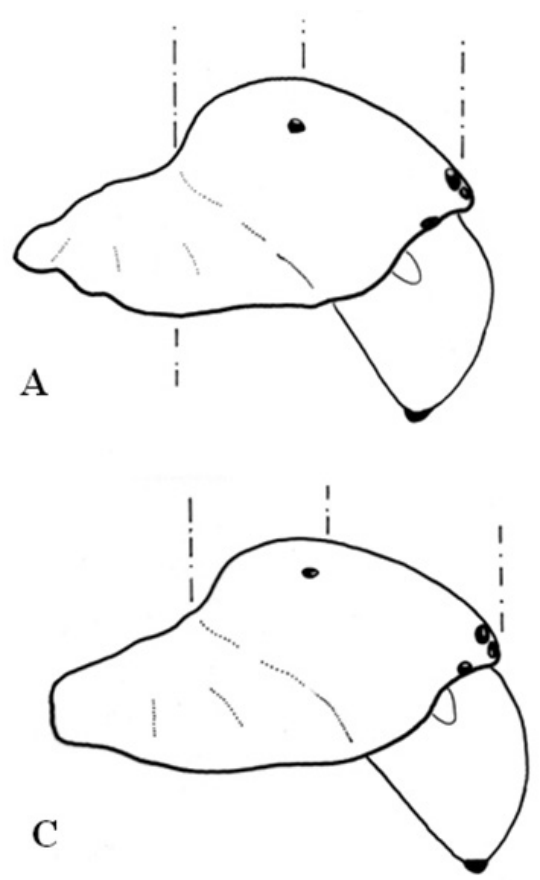
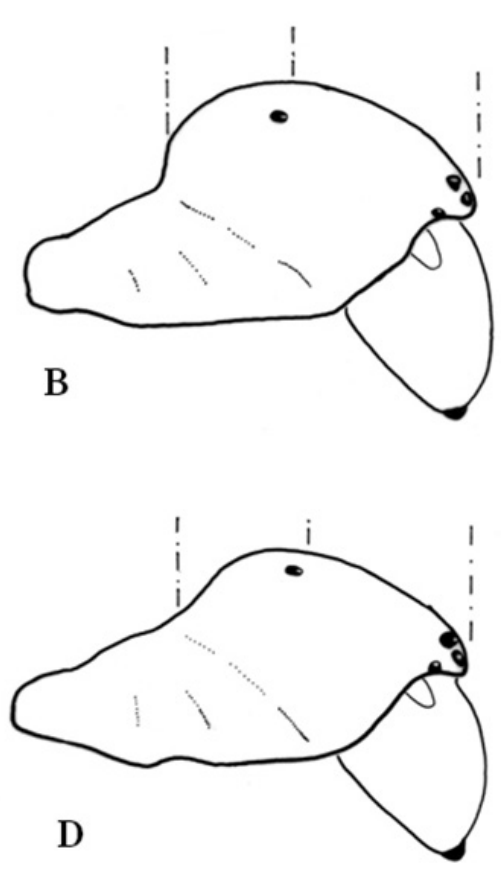

Figure 7. Outline of male prosomas of Eresus spp. belonging to the Eresus sandaliatus group, in lateral view A Eresus hermani B Eresus moravicus $\mathbf{C}$ Eresus kollari D Eresus sandaliatus (B, C, D after Fig 4. of Řzáč et al. 2008).

\section{Remarks on misidentifications.}

Cs. Szinetár (2006): p. 23. Fig. 3

The caption of this figure says "Female Eresus cinnaberinus", but, in fact, the picture shows a female Eresus hermani sp. n., as is evident from the heavy cover of light setae on the prosoma and the base of chelicerae. 
Kovács et al. (2010): figure 1C-F figure 2D

According to captions, fig. 1C-F of this paper depict the genital organs of female Eresus kollari. However, the anterior part of fissures of the epigyna are nearly parallel, epigynal pits are followed by large flat plateaus at the sides of median lobes, anterior copulatory ducts are round and weakly sclerotized, spermathecae strongly lobed, all features that distinguish Eresus hermani sp. n. unambiguously. Additionally, the epigyne shown in fig. $1 \mathrm{E}$ is grossly malformed, having supernumerary rudiments of fissures, a kind of abnormality frequent among females raised in captivity. Figure 2D is labeled as female Eresus kollari. Again, this figure shows a female Eresus hermani sp. n., as evidenced by the dense cover of lightly colored setae on the cephalic region and basal segments of chelicerae. The reason for these misidentifications is that at the time of writing, the authors (including the corresponding author of the present paper) considered females of Eresus hermani sp. n. as merely an extreme local variant of Eresus kollari. (Note: by contrast, fig. 2F. indeed shows a female Eresus kollari next to a male of the same species, as can be judged by the sparsely distributed light setae on the prosoma.)

Miller et al. (2012): figure $2 \mathrm{~A}$

Figure 2. A. of this paper is mislabeled as Eresus kollari, whereas in fact it depicts a female Eresus hermani sp. n. Again, the true identity of the specimen shown in this picture is revealed by the light color of the prosoma and basal chelicerae. The obvious reason for the misidentification is that at the time of the completion of this Atlas, the concept of Eresus hermani sp. n. as a discreet species was not yet formed.

Szinetár et al. (2012): table 2, figure 6

In this paper, figure 6. shows a female Eresus hermani sp. n. mislabeled as Eresus kollari. Heavy cover of the prosoma by lightly colored hairs gives away the identity of the depicted specimen.

\section{Acknowledgments}

We wish to thank Csaba Szinetár, Tamás Szűts, Milan Řezáč, and an anonymous reviewer for their valuable advice on the manuscript. We would like to thank József Mihály (BRC Hungary) for his assistance with light microscopy and Ákos Kukovecz (University of Szeged) for his approval of the use of the scanning electron microscope. We are especially grateful to Jørgen Lissner and Walter Pfliegler for consenting to the use of their photographs in this manuscript. We thank the following colleagues, who generously provided us with specimens and locality data: András Rákóczi, Balázs Somogyi, Dávid Viktor Nagy, Edit Vadkerti, Gergely Ambrus, István Hahn, János Bodor, Krisztina Bleicher, Lilla Lajos, Ferenc Samu, Márton Szabó, Mónika Landy-Gyebnár, Jørgen Lissner, Péter Kovács, Róbert Gallé, László Somay, Tünde Rácz, Walter Pfliegler, Orsolya Szentjobbi and László Dányi (HNHM, Budapest). We are grateful to Jennifer Tusz for correcting the English of our manuscript. 


\section{References}

Azarkina GN, Trilikauskas LA (2012) Spider fauna (Aranei) of the Russian Altai, part I: families Agelenidae, Araneidae, Clubionidae, Corinnidae, Dictynidae and Eresidae. Euroasian Entomological Journal 11(3): 199-208.

Chyzer K, Kulczynski L (1918) Ordo Araneae. A Magyar Birodalom Állatvilága - III - Arthropoda. Királyi Magyar Természettudományi Társulat, Budapest, 9 pp.

Herman O (1879) Magyarország pók-faunája. III./Ungarns Spinnen-Fauna, Dritter Band, Királyi Magyar Természettudományi Társulat, Budapest, 291-293.

Koch CL (1838) Die Arachniden Vierter Band. C. H. Zeh'schen Buchhandlung, Nürnberg. Kovács G, Szinetár Cs, Török T (2010) Data on the biology of Eresus species found in Hungary (Eresus kollari Rossi, 1846, Eresus moravicus Řezáč, 2008, Araneae, Eresidae). A NYME Savaria Egyetemi Központ Tudományos Közleményei, XVII. Természettudományok 12: 139-156.

Loksa I (1969) Pókok I. - Araneae I. Fauna Hungariae - Magyarország állatvilága, XVIII. kötet, Arachnoidea 2. füzet. Akadémiai Kiadó, Budapest, 18-20.

Miller JA, Griswold CE, Scharff N, Řezáč M, Szűts T (2012) The velvet spiders: an atlas of the Eresidae (Arachnida, Araneae). ZooKeys 195: 1-144. doi: 10.3897/zookeys.195.2342

Řezáč M, Pekár S, Johannesen J (2008) Taxonomic review and phylogenetic analysis of central European Eresus species (Araneae: Eresidae). Zoologica Scripta 37: 263-287. doi: 10.1111/j.1463-6409.2008.00328.x

Rossi FW (1846) Neue Arten von Arachniden des k. k. Museums, beschrieben und mit Bemerkungen über verwandte Formen begleitet. Naturwissenschaftliche Abhandlungen, Wien, 1, 11-19.

Samu F, Szinetár Cs (1999) Bibliographic check list of the Hungarian spider fauna. Bull. of Br. Arachnol. Soc. 11: 161-184.

Szinetár Cs (2006) Pókok. Kossuth Kiadó, Budapest, 112 pp.

Szinetár Cs, Rákóczi AM, Bleicher K, Botos E, Kovács P, Samu F (2012) A Sas-hegy pókfaunája II. A Sas-hegy faunakutatásának 80 éve - A hegyről kimutatott pókfajok kommentált listája. Rosalia 8: 333-362.

World Spider Catalog (2015) Natural History Museum Bern. http://wsc.nmbe.ch [version 16] 


\section{Appendix}

\section{Comparative materials examined}

Eresus kollari. Hungary: Remete-hegy, Budapest (1 9 , 19.09.2004., G. Kovács, HNHM Araneae-7689); Remete-hegy, Budapest (4 juv., 25.09.2005., G. Kovács, HNHM Araneae-7690); Remete-hegy, Budapest (2 Õ, 1 juv., 17.09.2006., G. Kovács, HNHM Araneae-7691); Remete-hegy, Budapest (1 o, 1 juv., 16.09.2007., G. Kovács, HNHM Araneae-7692); Remete-hegy, Budapest (3 $q$, 2 đ̃, 03.10.2007., G. Kovács, HNHM Araneae-7693); Remete-hegy, Budapest (4 $\overbrace{}^{\top}, 02.09 .2008$., G. Kovács, HNHM Araneae-7694); Remete-hegy, Budapest

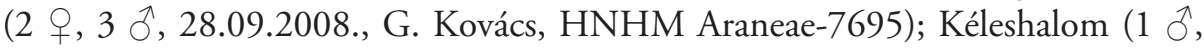
14.11.2010., H. Gyurkovics, G. Vári, HNHM Araneae-7696); Remete-hegy, Budapest (1 +, 02.04.2011., G. Kovács, HNHM Araneae-7697); Budakalász (3 §, 01.09.2011., I. Hahn, L. Somay, HNHM Araneae-7698); Remete-hegy, Budapest (1 q, 09.04.2011., G. Kovács, HNHM Araneae-7699); GyőrszentivánGönyü, Héricses (1 + , 28.11.2012., Cs. Szinetár, HNHM Araneae-7700); Farkas-hegy, Budaörs (2 ㅇ, 4 Oึ, 15.09.2013., G. Kovács, HNHM Araneae-7701); Győrszentiván (1 đ̃, 30.09.2013., P. Kovács, HNHM Araneae-7702); Sas-hegy, Budapest (3 Ô, 22.09.2010., E. Botos, PPI); Sas-hegy, Budapest (1 +, 16.07.2010., E. Botos, PPI); Sas-hegy, Budapest (1 9 , 09.10.2010., E. Botos, PPI); Sas-hegy, Budapest (1 đ̃, 07.10.1995., K. Bleicher, PPI); Gödöllő (1 đ̃, 30.08.2012., G. Ambrus, HNHM Araneae-7703); Belsőbáránd (1 Õ, ?10.2010., Cs. Szinetár, HNHM Araneae-7704); Bugac (2 ô, 24.09.2007., R. Gallé, HNHM Araneae-7705); Várpalota-Inota (1 +, 06.07.2014., G. Kovács, G. Vári, HNHM Araneae-7706), Ásotthalom (1 $\partial^{\lambda}, 20.10 .2013 .$, D. V. Nagy HNHM Araneae-7725), Mátyás-hegy, Budapest (2 §̂, 1933, G. Kolosváry, HNHM Araneae-2943).

Eresus moravicus. Hungary: Füzér, Castle hill (1 9 , (juvenile at the time of collection), 07.10.2006., Cs. Szinetár, G. Kovács, HNHM Araneae-7707); Misina-hegy, Pécs (1 đ̊, 22.04.2002., E. Vadkerti, HNHM Araneae-7708); Máriagyűd, Köves-máj (1 ठ̊, 08.05.2001, E. Vadkerti, HNHM Araneae -7709); Hárskút, Borostyán-he-

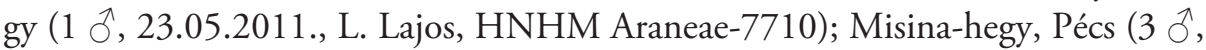
01.07.2011., E. Vadkerti, HNHM Araneae-7711); Felsőörs (1 §ૈ, 19.05.2011., M. Landy-Gyebnár, HNHM Araneae-7712); Cserkút (1 đ̊, 26.05.2013., P. Kovács, HNHM Araneae-7713); Tatárszentgyörgy (4 Ô, 19.05.2013., H. Gyurkovics, G. Vári, HNHM Araneae-7714); Tatárszentgyörgy (2 + , 1 ô, 19.05.2013., H. Gyurkovics, G. Vári, HNHM Araneae-7715); Tatárszentgyörgy (2 juv., 19.05.2013., H. Gyurkovics, G. Vári, HNHM Araneae-7716); Kelebia-Bácsborista (1 9,1 đ (juvenile at the time of collection), 1 juv., 02.10.2011., H. Gyurkovics, G. Vári, HNHM Araneae-7717); Kelebia-Bácsborista (1 đ̂, 30.05.2010., H. Gyurkovics, G. Vári, HNHM Araneae-7718); Misina-hegy, Pécs (3 +, 15.06.2012., G. Kovács, G. Vári, HNHM Araneae-7719); Szentgál, Tiszafás (1 đ̂, 21.05.2012., M., Szabó, HNHM Araneae-7720); Kelebia-Bácsborista (1 $\widehat{~}, 1$ †, 06.06.2010., G. 
Vári, HNHM Araneae-7721); Kelebia-Bácsborista (1 §̋, 24.05.2010., H. Gyurkovics HNHM Araneae-7723); Kelebia-Bácsborista (2 q, 06.06.2010., G. Kovács, HNHM Araneae-7724); Várpalota, Várvölgy (1 $\hat{\sigma}$, subadult at the time of collecting, 14.11.2014., G. Kovács, HNHM Araneae-7725). Austria: Dürnstein, (1 o, 07.06.2012., W. Pfliegler, WPPC).

E. sandaliatus. Denmark: Clasonsborg (1 juv., 12.05.2004, J. Lissner, JLPC); Tranemose moor, Northwest Jutland (1 O, 02.10.2006, J. Lissner, JLPC); Heather at Gindeskov Krat, Aulum (1 $\delta$, 06.08.2004, J. Lissner, JLPC); Heather at Stovbaek Krat near Aulum (1 juv., 08.06.2004, J. Lissner, JLPC); Norlund, north of Hallundbaek Stream (1 $\widehat{\jmath}, 28.10 .2011$, J. Lissner, JLPC); near the Danish-German border (1 q, 05.08.2006, J. Lissner, JLPC); Vind Hede (1 q, 30.09.2008, J. Lissner, JLPC). 